Article

\title{
A Non-Linear and Disaggregated Approach to Studying the Impact of CSR on Accounting Profitability: Evidence from the Polish Banking Industry
}

\author{
Łukasz Matuszak *(D) and Ewa Różańska *(D) \\ Department of Accounting, Faculty of Management, Poznań University of Economics and Business, \\ 60-681 Poznań, Poland \\ * Correspondence: lukasz.matuszak@ue.poznan.pl (Ł.M.); ewa.rozanska@ue.poznan.pl (E.R.)
}

Received: 1 December 2018; Accepted: 27 December 2018; Published: 1 January 2019

\begin{abstract}
Corporate social responsibility (CSR) is now extensively promoted in the European Union and highly desired by stakeholders. However, from a manager's point of view, the question of whether or not corporations should conduct CSR activities is controversial because of the accompanying high cost and uncertain benefits. The vast empirical literature appears to be rather inconclusive with respect to the question of whether CSR business engagement creates or destroys financial performance (FP). This study suggests that the inconsistent findings may be due to the use of aggregated CSR measures and a linear approach, as well as the omission of the industry or country context. Thus, the purpose of this study is to provide an updated assessment of the relationship between CSR and FP. Based on content analysis, we developed four individual CSR disclosure indices, corresponding to the environmental, human resources, product and customers, and community involvement dimensions, instead of an overall CSR composite score, and we examined their impact on accounting-based measures. We applied both linear and non-linear approaches. Data from Poland's banking industry for the period 2008-2015 provided the background for this study. Our results confirm the existence of a U-shaped relationship between human resources and FP, and an inverse-U-shaped relationship between FP and community involvement, and FP and product and customers. This study contributes not only to the CSR literature by providing new insights into this relationship between CSR dimensions and FP, but it also offers policy suggestions for both bank managers and government regulators.
\end{abstract}

Keywords: corporate social responsibility; CSR disclosure; financial performance; non-linear relationship; banking industry; Poland

\section{Introduction}

In recent years, the concept of corporate social responsibility (CSR) has been promoted extensively by authorities in the European Union (EU), mainly because of its pioneering role in fostering sustainable development, innovation, and competitiveness in the EU's social market economy. The European Commission (EC) defines CSR as "the responsibility of enterprises for their impacts on society," and stresses that "to fully meet their corporate social responsibility, enterprises should have in place a process to integrate social, environmental, ethical and human rights concerns into their business operations and core strategy in close collaboration with their stakeholders." [1]. The EC believes that CSR provides important benefits to enterprises in risk management, cost savings, access to capital, customer relationships, and human resource management. Hence, the concept of CSR is widely debated in both the corporate and the academic worlds. The current literature [2] notes a change in the theoretical orientation in 
which the concept of CSR is understood and researched. There has been a shift from ethics-oriented studies at the macro level towards performance-oriented studies focused on the organizational level. This 'progressive rationalization' of the concept has moved the discussion from whether CSR is necessary to how to implement it in order to deliver optimum benefits, and hence justify the decision to act. Managers are faced with the dilemma of whether or not companies should engage in CSR activities, considering not only an ethical but, above all, a business case. The decisive question that has to be answered is whether CSR is associated with an increase in company financial performance (FP). The answer to this question allows managers to provide evidence supporting rational decisions regarding the implementation of CSR. Freeman et al. [3] argue that the company's aim is to meet the needs of all stakeholders; if this is done, profit will be made. In this view, profit is a consequence of the company's activity, including CSR initiatives. Thus, understanding the financial profitability of CSR activities seems to be more important than their social benefit. Freeman et al. [3] maintain that if there are conflicting interests between stakeholders, the company must not choose one over the other but must find a compromise, a third way which will meet both interests. Therefore, Freeman et al. [3] maintain that CSR encourages innovation because it opens the door to a world of possibilities. Briefly put, it gives managers the opportunity to invest simultaneously for profit and social benefits. It should also be added that, according to Farrington et al. [4] a business-oriented approach is useful as long as it confirms the need for research, taking into account local and national industrial nuances. The existing literature appears to be rather inconclusive with respect to the question of whether CSR activity can be translated into positive FP. According to a recent in-depth review on the CSR-FP relationship [5], the findings are still inconsistent and disappointing. Although the majority of studies report a positive relationship [6-15], some report a negative relationship [16-18], non-significant findings [19-22], or mixed results [23-26]. A commonly identified reason for these diverse, and at times even contradictory, results is the choice and measurement of both the CSR and FP constructs $[27,28]$.

Regarding the CSR construct, most empirical research relies on reputation ratings or other externally visible measures, in particular the Kinder, Lydenberg, and Domini (KLD) database [5]. Such measures carry the advantage of availability, but also have many weaknesses. One particular drawback is that they are typically compiled by private companies that have their own agendas and do not necessarily use scientific methods [29]. Another major disadvantage is a limited coverage of companies rated. Indices typically focus on large, listed, and well-known firms, and cover a particular region or country. Moreover, some measures like the KLD database exclude companies operating in industries considered non-sustainable [28], and they lack sector specificity [21]. Beyond the above limitations of the measures provided by independent bodies, the literature shows that, despite relying on the same KLD database, the concept of CSR is operationalized differently and it is almost impossible to compare the findings of studies [5]. Most of those studies relied on aggregated CSR scores [6-10,12-14,22,30-32], which are fundamentally flawed. The use of composite measures leads to the problem of likely imperfect correlation of the individual CSR components [33,34], and potentially produces inaccurate results [13]. Such studies failed to recognize the heterogeneous nature of stakeholders' objectives and expectations. Only a few studies have paid more attention to specificity consistent with stakeholder theory and examined the individual dimensions of CSR [11,16,23,24,35]. To overcome some of the deficiencies of the CSR measures commonly used in the literature, alternative CSR measures should be considered [36]. Other approaches to measure CSR need also to be tested to assess whether the current results of the literature are robust to different datasets [37].

To measure the dependent construct, that is, FP, researchers relying on either accounting-based measures or market-based measures [5] have pointed out that the theoretical conceptualizations underlying each FP approach are different, so these approaches show different aspects of financial performance. Accounting-based indicators reflect past, short-term FP, while market-based indicators reflect future, long-term FP. Many studies $[6,18,31,37]$ have used these indicators interchangeably in robustness checks, which is a substantial flaw, namely, a mismatch between theory and construct [5]. According to recent thorough reviews $[5,38]$ on CSR-FP links, there is a slight preference for the 
application of market-based measures, although it is questionable whether these measures are suitable for studying the CSR and FP relationship. The groundlessness of using these measures results from the fact that market-based indicators merely reflect investors' expectations, and are based on the questionable market efficiency hypothesis. In this situation, relying on accounting measures is a better approach if the construct is based on stakeholder theory or resource-based theory [5].

Another reason for the inconsistency of existing research on CSR and FP relationships may be model specification. The majority of studies only test for a linear relationship between a company's CSR and its FP. However, recent developments in microeconomic theory suggest that a non-linear set-up should be considered $[39,40]$. A curvilinear (U-shaped or inverse U-shaped) relationship between CSR and FP is therefore in line with economic intuition, but has rarely been tested [37,41-43]. The choice and measurement of both CSR and FP constructs, as well as model specification, partly explain the inconsistent research outcomes.

Apart from the divergent ways in which CSR and FP were treated by researchers and the specifications that were tested, the empirical literature also suffers from some fundamental shortcomings which further contribute to the examination of CSR-FP relationships. Even though most studies claimed to be based on stakeholder theory, they examined multiple countries [32,44], multiple industries $[10,16,37,45]$, or both multiple industries and multiple countries $[14,46,47]$. In the context of country, most of studies were almost exclusively restricted to US firms, due to the widespread application of the KLD database [5]. Such studies ignored the fact that stakeholders' attributes vary by industrial and national contexts [16,22], and are also dynamic over time [48]. Cultural, institutional, and regulatory differences between countries can lead to different stakeholder expectations and, as a consequence, different CSR initiatives [49]. Therefore, Grewatsch and Kleindienst [5] encouraged researchers to move beyond the US context and conduct more studies involving non-US firm samples.

Responding to these gaps and shortcomings of the existing literature, the purpose of this study is to provide an updated assessment of the relationship between CSR and FP. In so doing, we examined the impact of individual CSR dimensions disclosed by Polish commercial banks on their accounting returns for the period 2008-2015.

Based on content analysis, we examined the individual CSR disclosure scores, i.e., the environmental, human resources, product and customers, and community involvement scores, instead of the overall CSR composite score. Aggregating the CSR scores is at odds with stakeholder theory and would be inappropriate for this study. To measure individual CSR, we used content analysis as an alternative method to that commonly used in the literature. Galant and Cadez [28] have argued that this method has the benefit of high flexibility for the researcher. A researcher can specify CSR dimensions of interest, collect information concerning these dimensions, and code information numerically for further use in statistical analyses. In this study, we disentangled the CSR disclosure score into its four components so that we could identify the key drivers of FP. To measure FP, we focused on accounting-based measures. We used two different indicators, net interest margin (NIM) and average return on assets (ROA), for robustness purposes. As in Grewatsch and Kleindienst [5], we considered that relying on accounting measures was a better approach if the construct was based on stakeholder theory.

In terms of model specification, we would like to remark that our research was motivated by the few works $[37,41-43,50]$, so far, that have documented a curvilinear relationship between CSR and FP. We tried to answer the following research questions and to test the associated hypotheses: Is there any relationship between individual CSR disclosure and accounting returns? If so, is it positive or negative? Furthermore, if the relationship is a mixed or inclusive one, what would be the alternative solution? For these reasons, we examined both the linear and non-linear relationships between CSR and FP. Our research questions were necessitated partly by the dominance of linear models and an inadequate focus on the individual CSR disclosures, as well as accounting-based measures.

This research was done in the banking sector. Banks were selected for the study mainly because of two reasons. First, the mainstream opinion underlines the need for banks to be involved in CSR, as banks benefit significantly from society and should repay that benefit. Banks use considerable 
resources from society instead of their shareholders, especially in the form of capital. In many countries, bank deposits are guaranteed by the state and, during a financial crisis, banks may also receive public funds to avoid collapse. Thus, from the view of regulator and the public, engagement in CSR activities is a means for banks to compensate for these privileges, regardless of whether the business is profitable. However, from a bank manager's view, the question of whether or not banks should conduct CSR activities is controversial because of the accompanying high cost, even if banks could enjoy the benefits of a higher income as a result of their good reputation [15]. Second, the banking sector is still under-researched in the area of CRS and FP relationships. The few existing studies offer conflicting evidence [22,32]. Moreover, the studies that have examined the banking industry adopted aggregated CSR measures, and failed to decompose the measures into their various components [15]. Previous studies within the banking industry also did not consider nonlinear relationships between CSR and FP [51]. This research analyses the issue in a more exhaustive way.

In the context of the recent financial crisis, which strongly affected banks' financial performance, the relationship between CSR and FP could be obscured in the subsequent period. Earlier papers [15,32] did not control for an endogeneity problem, as they used a data set from different countries that includes the period of crisis, as well as pre-crisis or post-crisis periods. Some research to avoid this endogeneity problem partially investigated the relationship between CSR and FP before the crisis [22,44] after the crisis [52], or around the crisis [53]. The scope of this study did not exclude the crisis period, so to limit the impact of the financial crisis on the CSR and FP relationship, we focused on banks that were not significantly affected by the crisis. For this reason, we chose commercial banks operating in Poland. According to the research [54] regarding the banking sector in the European Union, the Polish banking sector was only slightly affected by the financial crisis. The Polish banking sector, compared to the banking sectors of the European Union, is distinguished by having both the highest average ROE (12.3\%) and the highest average ROA (1.26\%) in 2008-2013, i.e., five years after the outbreak of the financial crisis. In 2013, the ROA in the Polish banking sector stood at $0.99 \%$, which is three times higher than the average in the European Union.

In short, our results in a linear model suggested that the effect of CSR dimensions on FP is mixed and insignificant. However, when a non-linear model was used, we found evidence of both U-shaped and inverse-U-shaped relationships between CSR disclosure indices and the accounting-based measures in the Polish banking sector. More precisely, our results confirmed the existence of a U-shaped relationship between human resources and net interest margin, and an inverse-U-shaped relationship between community involvement and net interest margin, as well as between product and customers and return on assets in Polish banks. Previous studies [37,43] aggregated multiple social dimensions like employees, customers, and community relations, and ignored Brammer and Millington [26], who claimed that actions in each of these spheres may impact firm performance differently. They therefore failed to find a non-linear relation between social performance and financial performance. Hence, our study provides new insights into this relationship between specific dimensions of CSR and firm performance.

This study differs from previous studies in three aspects. First, the present study focused on the individual CSR dimensions specific to the banking sector, making this study unique by filling a knowledge gap through the identification of the nature and significance of the effect which each component has on a bank's financial performance. Another unique feature of this study was its focus on the rarely examined net interest margin as a key measure of financial performance in the banking sector. Second, the current study is the first to test the nonlinearity of selected social variables such as human resources, product and customers, and community involvement. We found that all social dimensions exhibited a significant U-shaped or an inverse-U-shaped relationship with banks' FP. This finding has not been previously reported, and adds to the discussion regarding the U-shaped CSR-FP relationship started by Barnett and Salomon [41]. By contrast, no significant relationship can be reported for the environmental dimension. This result is consistent with Nollet et al. [37]. The improved understanding of the CSR-FP relationship fills a knowledge gap in the literature. 
Third, unlike previous studies [37,43], we focused solely on the banking sector. Furthermore, instead of US data we considered longitudinal data from a European country. To the best of our knowledge, our study is the first to test the non-linear relationship between CSR dimensions disclosed by banks, not only in Poland, but also in Europe and worldwide.

This research contributes not only to the CSR literature, it also provides policy suggestions for both bank managers and government regulators to ensure optimal allocation of resources to competing social activities in a manner that may maximize FP and improve overall stakeholder wellbeing.

The remainder of this paper is organized as follows. The next section briefly discusses the theoretical background of the study, reviews the existing literature, and develops hypotheses. Following this we present the data, variables and the research methodology. In the subsequent section, we discuss the empirical results and their interpretation. Finally, we present theoretical and practical implications of the study. The article concludes with a recommendation regarding future research agendas.

\section{Literature Review and Development of Hypotheses}

The literature from the last 40 years includes a huge number of studies that have investigated the possible relationship between CSR and FP, both theoretically and empirically. From the theoretical point of view, two conflicting hypotheses regarding the relationship between CSR and FP have been proposed: the positive relationship (the social impact hypothesis) and the negative relationship (the trade-off hypothesis). The social impact hypothesis puts forward a positive association between CSR and FP. Proponents of stakeholder theory [55] believe that to be successful, firms must engage in socially responsible activities to meet the needs and expectations of a wide array of stakeholders, which includes groups other than shareholders. In so doing, companies build trust and reputation, which leads to many other benefits, for example, employee, customer, and local community loyalty, and consequently improved FP. Margolis et al. [36] found that CSR engagement helps firms gain a competitive advantage. Among the desirable effects of CSR activity, Khlif et al. [56] mentioned increased employee motivation and productivity, increased product acceptance among customers, and increased acceptance among investors who support social or environmental values. Overall, the expected benefits of CSR disclosures may largely exceed their costs, resulting in stronger corporate financial performance.

By contrast, the trade-off hypothesis presents a negative association between both variables (i.e., CSR and FP). This so-called traditionalist view, which is generally credited to Friedman [57], argues that corporate interests should not stray from those of investors. Specifically, allocation of resources to accomplish social goals essentially adds to costs and runs counter to the firm's conventional objective to maximize profit. Examples of inefficient use of resources include investments in pollution reduction, higher employee wages and benefits, and donations and sponsorships for the community. The conventional view maintains that these expenses will harm profitability and lead to 'competitive disadvantage' [28]. As can be seen, the theoretical justifications suggest both a potentially negative and positive relationship between CSR and FP. The question arises whether empirical literature indicates the general relationship between CSR and FP.

Although the body of empirical studies that consider FP as a consequence of CSR is vast, it appears to be rather inconclusive with respect to the question of whether CSR activity can be translated in terms of a positive or negative effect on a firm's FP. Among the studies that have examined multiple industries, multiple countries, or both multiple industries and multiple countries, studies have reported positive, negative, and neutral, as well as U-shaped or inverted-U-shaped, relationships between CSR and FP. Some studies have identified a positive relationship between CSR and FP [6,8-14], suggesting that being socially responsible improves profitability. On the contrary, some studies point to a negative relationship [16-18]. This finding is consistent with Friedman's view that social responsibility incurs costs and harms profitability. The third documented relationship is a neutral relationship [19-21]. Studies within this stream suggest that being socially responsible does not improve profitability, but it 
also does not hurt it. The positive and negative effects of CSR apparently cancel themselves out. The last detected relationship between CSR and FP is U-shaped or inverted U-shaped. This group of research assumes that a positive or negative relationship can occur, depending on the level of CSR [26]. Bowman and Haire [50] documented an inverted-U-shaped relationship. This means that mediocre CSR is related to the highest financial performance whereas low and high CSR are related to lower financial performance. Interestingly, many years later, Barnett and Salomon [41,42] provided some empirical evidence for the existence of a U-shaped relationship between CSR and FP, i.e., the highest and lowest levels of CSR were associated with the highest levels of FP based on firm-level data. Mittal et al. [58] justified the expected U-shaped relationship between CSR and FP. According to these authors, the negative relationship could be observed at an earlier stage of CSR activity because the cost of CSR caused the initial downward slope of the U curve. Supporting this conjecture, Nollet et al. [37] developed a non-linear panel regression model and empirically proved the existence of a U-curve-shaped relationship between corporate governance and FP in US corporations. The same relationship was found by Han et al. [43] in Korean corporations between the environment dimension and FP, but the opposite pattern was confirmed (inverse-U-curve relationship) between corporate governance and FP.

A possible explanation for such inconsistent findings is the combining the CSR ratings of different industries and different countries. As stakeholders' goals, objectives, and aspirations tend to differ across the contexts of industrial and national boundaries [16], they can lead to different CSR initiatives [49]. A better approach is therefore to conduct studies in the context of each industry and each country $[16,22]$.

Considering the banking sector, direct studies of the CSR-FP relationship are rare and also offer conflicting evidence. For example, Chih et al. [44] empirically investigated a total of 520 financial firms in 34 countries between the years 2003 and 2005, and concluded that CSR and financial performance were not related. No relationship between CSR and FP was also presented in Soana [22], based on a sample of Italian banks. Similar results were found in Matuszak and Różańska [51], based on a sample of Polish banks. In conflict with the social impact hypothesis, statistical analysis showed that CSR did not significantly predict accounting returns. In contrast, $\mathrm{Wu}$ and Shen [32] analyzed 162 banks in 22 countries over 2003-2009, and reported that CSR was positively associated with financial performance in terms of ROA, ROE, net interest income (NII), and noninterest income (NonII) ratios. They also found that CSR was negatively associated with the non-performing loans ratio. Another study of Shen et al. [15], which used data from global banks in 18 countries over 2000-2009, also supported the social impact hypothesis. They confirmed that banks engaging in CSR activities had higher ROA, ROE, NII, and NonII ratios, and a lower NPL ratio, than banks that did not engage in CSR activities. In the context of the recent financial crisis, Cornett et al. [53] proved that US banks, in general, appear to be rewarded for being socially responsible, as ROE is positively and significantly related to CSR scores in both pre-crisis and post-crisis periods. The mixed results of different studies with regard to the CSR-FP relationship in the banking industry may be attributed to measurement issues and model specification, as well as different sample periods. To this day, although the multi-dimensional nature of social performance is widely recognized, studies examining the banking industry have adopted aggregated CSR measures. Previous studies within the banking industry also have not considered nonlinear relationships between CSR and FP. This study proposed to analyze the issue in a more exhaustive way. We focused on the individual CSR dimensions specific to the banking sector, such as human resources, product and customers, and community involvement, and tested both the linear and nonlinear relationships between selected CSR variables and accounting profitability.

Based on the theoretical justifications, empirical literature, and our research questions, the following hypotheses were tested: 
Hypothesis 1 (H1). There is a linear and positive effect of CSR dimensions disclosure (environment, human resources, product and customers, community involvement) on accounting profitability measures (ROA, NIM) in Polish banks.

Hypothesis 2 (H2). The effects of the environment, human resources, product and customers, and community involvement disclosure on accounting profitability are non-linear, implying that the relationship could be convex (U curve) or concave (inverse $U$ curve).

The research framework developed in the paper is shown in Figure 1.

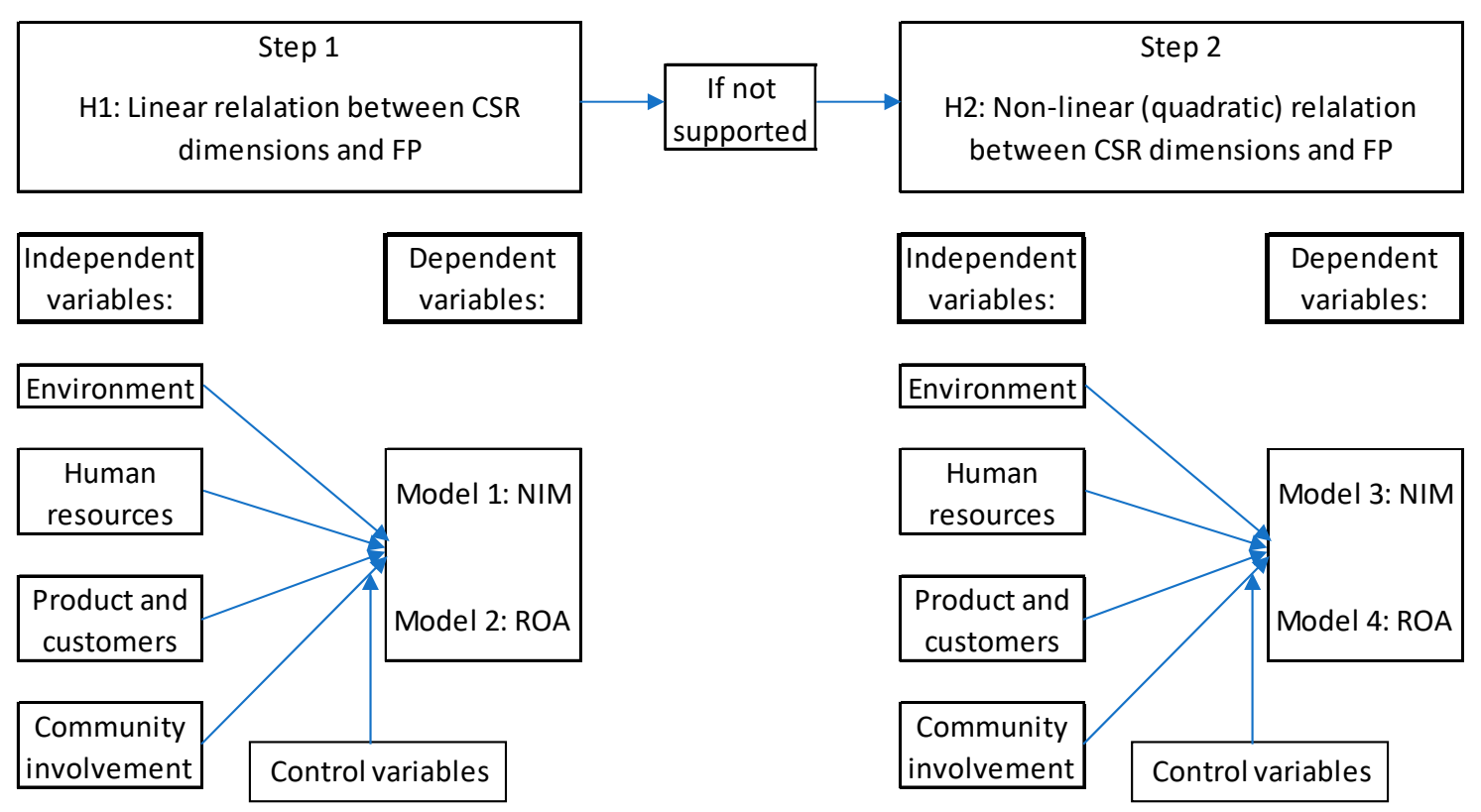

Figure 1. The research framework.

\section{Data and Variables}

\subsection{Data Description}

This study investigated the effect of CSR on FP in both linear and non-linear relationships. The sample consisted of all commercial banks that operated in the years 2008-2015 in Poland, if their financial statements were available on their websites. Representative offices of foreign banks and credit institutions were excluded from the research sample, since they represented a small market share and most of them had very few branches. The final sample comprised 18 commercial banks, of which 11 were listed on the Warsaw Stock Exchange. Therefore, the overall sample included 144 bank-year observations. All of the data used in this paper were hand-collected from financial statements, management commentaries, and corporate social responsibility reports that were available on banks' websites for the years 2007-2015. Financial data were obtained from publicly available financial statements. Absolute values were standardized using their natural logarithms to make them appropriate for linear regression analysis.

\subsection{Variables}

\subsubsection{Dependent Variables}

To measure FP, we used NIM and ROA ratios. The methodology applied for construction of these measures is presented in Table 1. NIM is one of the key measures of bank profitability, as in most banks the largest share of revenue comes from interest on loans. Simpson and Kohers [59] state this kind of revenue affects net income and capital, which determine financial success. The higher the net 
interest margin, the higher the bank's profit and the more stable the bank. In turn, ROA is probably the most widely recognized measure of financial performance. ROA measures how efficiently the resources of the bank are used to generate its income. Both variables are accounting-based measures, since we have not included investor perception in our theoretical background. According to Grewatsch and Kleindienst [5], relying on accounting measures is the best approach if the construct is based on stakeholder theory. Moreover, as van der Laan et al. [24] have stated, it would not be reasonable to assume efficient stock markets in the context of CSR. An individual investor should pay attention not only to his private social demands, but to those of other stakeholders as well.

Table 1. Variables, required data and data sources.

\begin{tabular}{|c|c|c|}
\hline Variables & Description & Source \\
\hline Dependent variables & \multirow{3}{*}{$\begin{array}{l}\text { ROA }=\text { net profit/average of total assets } \\
\text { NIM = net profit on interests/average of } \\
\text { total assets }\end{array}$} & \\
\hline Average Return on Assets (ROA) & & Financial statements \\
\hline Net Interest Margin (NIM) & & Financial statements \\
\hline \multicolumn{3}{|l|}{ Independent variable } \\
\hline Environmental disclosure index (ENV) & \multirow{4}{*}{$\begin{array}{l}\text { Indices based on a list of } \\
\text { disclosures-Table } 2\end{array}$} & \multirow{4}{*}{$\begin{array}{l}\text { Management } \\
\text { commentaries } \\
\text { CSR reports }\end{array}$} \\
\hline Human resources disclosure index (HR) & & \\
\hline Products and customers disclosure index (PC) & & \\
\hline Community involvement disclosure index $(\mathrm{CI})$ & & \\
\hline \multicolumn{3}{|l|}{ Control variables } \\
\hline Net Log of Total Assets (LogTA) & \multirow{4}{*}{$\begin{array}{l}\text { LogTA }=\text { natural logarithm of total assets } \\
\text { Leverage }=\text { debt } / \text { total equity } \\
\text { Dummy }=1 \text { if bank is listed on Warsaw } \\
\text { Stock Exchange and } 0 \text { otherwise }\end{array}$} & \multirow{4}{*}{$\begin{array}{l}\text { Financial statements } \\
\text { Financial statements }\end{array}$} \\
\hline Leverage ratio (Leverage) & & \\
\hline WSE & & \\
\hline & & \\
\hline
\end{tabular}

\subsubsection{Independent Variable-Measure of CSR}

Previous studies regarding the CSR-FP link in the banking industry have adopted aggregated measures of the CSR construct, including reputation ratings such as the AEI Index [22], and other externally visible measures, such as ratings data from the MSCI ESG STATS database (formerly the KLD [53] or EIRIS Index [32]), as well as disclosure [51]. In this study, we employed content analysis of CSR information disclosed by banks, based on the multidimensional scale developed by Matuszak and Różańska [51]. This scale contains a list of 29 items specific to the banks, assigned to more general dimensions (environment, employees, customers, and society), that correspond to the four key stakeholder groups in the banking sector (see Tables 1 and 2). In terms of operationalization, we analyzed the existence or absence of particular CSR disclosures (understood as descriptive and/or numerical information) in bank reports, namely, management commentaries and CSR reports. We used the approach of assigning a value of 1 if an item of CSR disclosure was reported and 0 otherwise, no matter the communication channel. For example, if the disclosure item was presented in two reports by a bank, the presence of the item was treated once. Realizing that the main weaknesses of this approach to measure CSR is researcher subjectivity [28], we employed a cross-check analysis (scores given by one author were checked independently by the second author, and conversely). Discrepancies across members of the research team were discussed and reconciled. In addition, following prior studies [60], we used Cronbach's alpha coefficient to assess the internal consistency of the employed scale. Its value ranges between 0 and 1 , with a value higher than 0.70 indicating a sufficient level of reliability. The alpha coefficient value here was 0.9468 , which indicates that the items included in the scale captured the same underlying construct.

In contrast to previous studies [51], we disentangled the CSR performance into dimensions, namely, environment (ENV), human resources (HR), product and customers (PC), and community 
involvement (CI), instead of using the overall CSR composite index. The list of CSR dimension items is presented in Appendix A. Thus, we calculated four indices for each bank as follows:

$$
\begin{aligned}
\mathrm{ENV} & =\mathrm{N}_{1} / 10 \times 100 \\
\mathrm{HR} & =\mathrm{N}_{2} / 8 \times 100 \\
\mathrm{PC} & =\mathrm{N}_{3} / 6 \times 100 \\
\mathrm{CI} & =\mathrm{N}_{4} / 5 \times 100
\end{aligned}
$$

where:

$$
N_{i} \text {-number of items disclosed by the bank in each category. }
$$

Given that the effects of one dimension sometimes cancel out the opposing effects of another dimension [36], this disaggregation provided us with the advantage of detecting which CSR dimension was a key driver for improving FP. In order to strengthen the predictive capability of the regression models proposed in our study, we properly lagged the CSR reporting indices. A 1 year lag of independent variables permitted us to test the causal relationship between CSR and the FP. This approach is a growing feature of the current literature [37]. We assumed that effects of CSR do not occur immediately and that it takes some time to generate the expected returns.

\subsubsection{Control Variables}

Following previous studies [15,32], we included in our model the following control variables: firm size, (un)systematic risk, and a dummy variable indicating whether the bank was listed on the stock exchange market (Table 1). To standardize the absolute values of total assets, and to avoid non-normality of the distribution, the natural logarithm of total assets was used (LogTA). The proxy measure for (un)systematic risk employed in this study was the leverage ratio (Leverage). In order to control the effect of being listed on the Warsaw Stock Exchange (WSE), we employed the dummy variable WSE. Banks that are listed on the stock exchange are under more pressure to generate stronger financial results compared to unlisted banks. Consistent with the current literature [15], we expected that banks' financial performance would be positively associated with size and WSE, while it would be negatively associated with the leverage ratio.

\section{Methodology and Empirical Models}

In our analysis, we employed ordinary least squares (OLS) regressions. Since we detected the presence of heteroscedasticity problems, we used robust standard errors to remove heteroscedasticity. Robust standard errors can give efficient estimates of the coefficients when the residuals are only heteroscedastic [61]. Further, we employed the Ramsey regression specification error test (RESET) test to assess whether a linear model specification was appropriate. Ramsey's regression specification error test detects general functional form misspecification. To implement RESET, it is necessary to decide how many functions of the fitted values to include in an expanded regression. In fact, there is no right answer to this question [61]. That is why in our research, if linear models were not appropriate, based on prior literature [37,43], we assumed and estimated non-linear quadratic models.

\section{Empirical Model}

The focus of this study was to examine the impact of different dimensions of CSR on FP. In most previous studies, CSR was treated as a single construct, thereby simplifying the approach to a multidimensional construct [51]. Thus, in this research we considered the extent of CSR in four dimensions, namely: environment, human resources, products and customers, and community 
involvement. The use of such individual CSR dimensions in the linear and non-linear models is our original concept. The regression model can be specified by the following equation:

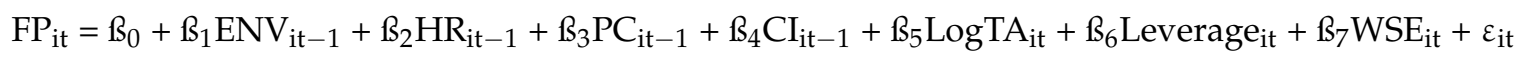

where

$\mathrm{FP}_{\mathrm{it}}$ - Financial performance proxied by ROA and NIM of bank $\mathrm{i}$ at time $\mathrm{t}$,

$\mathrm{ENV}_{\mathrm{it}-1}$ - lagged environment disclosure index $\mathrm{i}$ at time $\mathrm{t}-1$,

$\mathrm{HR}_{\mathrm{it}-1}$ - lagged human resources disclosure index $\mathrm{i}$ at time $\mathrm{t}-1$,

$\mathrm{PC}_{\mathrm{it}-1}-$ lagged products and customers disclosure index $\mathrm{i}$ at time $\mathrm{t}-1$,

$\mathrm{CI}_{\mathrm{it}-1}$-lagged community involvement disclosure index $\mathrm{i}$ at time $\mathrm{t}-1$,

$\log \mathrm{TA}_{\mathrm{it}}-$ natural logarithm of total assets of bank $\mathrm{i}$ at time $\mathrm{t}$,

Leverage $_{i t}$-leverage ratio of bank $i$ at time $t$,

$\mathrm{WSE}_{\mathrm{it}}$-dummy $=1$ if bank is listed on Warsaw Stock Exchange and 0 otherwise

$\mathrm{B}_{0}$-an intercept,

$B_{1} \ldots 7$-a vector of exogenous variables and observations,

$$
\begin{gathered}
i=1,2, \ldots, N, \text { index of bank, } \\
t=1,2, \ldots, T, \text { index of time. }
\end{gathered}
$$

Further, we examined the quadratic relationship between CSR disclosure indices and FP in order to consider the possibility of a quadratic relation. In this case, the regression model was specified by the following equation:

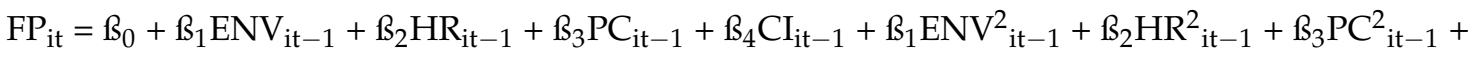

$$
\begin{aligned}
& \beta_{4} \mathrm{CI}^{2}{ }_{\text {it }-1}+\aleph_{5} \operatorname{LogTA} A_{i t}+\beta_{6} \text { Leverage }_{i t}+\beta_{7} \mathrm{WSE}_{i t}+\varepsilon_{\text {it }}
\end{aligned}
$$

where

$\mathrm{ENV}^{2}{ }_{\mathrm{it}-1}$ - lagged squared environment disclosure index $\mathrm{i}$ at time $\mathrm{t}-1$,

$\mathrm{HR}^{2}{ }_{\mathrm{it}-1}$ - lagged squared human resources disclosure index $\mathrm{i}$ at time $\mathrm{t}-1$,

$\mathrm{PC}^{2}{ }_{\mathrm{it}-1}$ - lagged squared products and customers disclosure index $\mathrm{i}$ at time $\mathrm{t}-1$,

$\mathrm{CI}^{2}{ }_{\text {it-1 }}$-lagged squared community involvement disclosure index $\mathrm{i}$ at time $\mathrm{t}-1$,

\section{Empirical Findings and Discussion}

\subsection{Descriptive Statistics}

Table 3 depicts the development of lagged CSR indices for the years 2007 to 2014. The reporting level of each CSR index increased over the years of analysis. This is a positive trend among Polish banks. Comparing 2007 and 2014, we can state that commercial banks have strongly improved their CSR dimensions. In each year, banks engaged the most in community matters. This demonstrates the strong commitment of the banks to charity, volunteering, and sponsorship. Moreover, banks' commitment in areas of HR and PC was quite similar within the analyzed period. From 2007 to 2014, HR and PC scores increased $230.7 \%$ and $205.7 \%$, respectively. The dimension with the lowest level of disclosure was environment, however, an upward trend was observed. From 2007 until 2014, this 
level increased from $13 \%$ to $31 \%$. Thus, banks have still much to do to improve the level of reporting, especially in the area of environment.

Table 2. Overall extent of CSR reporting for the years 2008 to 2015.

\begin{tabular}{|c|c|c|c|c|}
\hline Sr. No. & Items of CSR Dimensions & $\begin{array}{l}\text { No. of Banks } \\
\text { Reported This Item }\end{array}$ & $\%$ & Frequency \\
\hline & Environment (ENV) & & & \\
\hline 1 & Statement on environmental protection policy & 10 & $55.6 \%$ & 68 \\
\hline 2 & Prevention of pollution (waste disposal and recycling) & 9 & $50.0 \%$ & 50 \\
\hline 3 & $\begin{array}{l}\text { Actions aiming to limit consumption of energy, materials, } \\
\text { water (sustainable use of resources) }\end{array}$ & 9 & $50.0 \%$ & 51 \\
\hline 4 & Sustainability (any mention of sustainable development) & 9 & $50.0 \%$ & 54 \\
\hline 5 & $\begin{array}{l}\text { Aesthetic value of the environment (designing structures } \\
\text { in harmony with the environment, landscape) }\end{array}$ & 1 & $5.6 \%$ & 5 \\
\hline 6 & $\begin{array}{l}\text { Environmental protection, biodiversity and restoration of } \\
\text { natural habitats }\end{array}$ & 8 & $44.4 \%$ & 36 \\
\hline 7 & $\begin{array}{l}\text { Taking account of the environment in credit policy } \\
\text { (environmentally-friendly products, 'green products', } \\
\text { funding 'low-emission' investment projects ... ) ) }\end{array}$ & 9 & $50.0 \%$ & 46 \\
\hline 8 & Environmental training and certificates (ISO $14001 \mathrm{vs)}$ & 6 & $33.3 \%$ & 21 \\
\hline 9 & $\begin{array}{l}\text { Joint projects with other companies providing } \\
\text { environmental management services }\end{array}$ & 1 & $5.6 \%$ & 7 \\
\hline 10 & Environmental awards & 7 & $38.9 \%$ & 17 \\
\hline & Human Resources (HR) & & & \\
\hline 11 & Employment and labour relations & 15 & $83.3 \%$ & 101 \\
\hline 12 & Occupational health and safety & 13 & $72.2 \%$ & 53 \\
\hline 13 & Employee development (training ... ) & 15 & $83.3 \%$ & 97 \\
\hline 14 & $\begin{array}{l}\text { Employee benefits (insurance, healthcare, social } \\
\text { assistance ... ) }\end{array}$ & 13 & $72.2 \%$ & 59 \\
\hline 15 & Relationships with trade unions & 12 & $66.7 \%$ & 45 \\
\hline 16 & Information on employee turnover & 13 & $72.2 \%$ & 53 \\
\hline 17 & $\begin{array}{l}\text { Information on support for daytime care, maternity and } \\
\text { paternity leave }\end{array}$ & 9 & $50.0 \%$ & 25 \\
\hline 18 & $\begin{array}{l}\text { Encouraging diversity (employment of minorities, } \\
\text { disabled persons, women ....) }\end{array}$ & 10 & $55.6 \%$ & 27 \\
\hline & Product and customers (PC) & & & \\
\hline 19 & Comprehensibility and transparency of products/services & 15 & $83.3 \%$ & 71 \\
\hline 20 & $\begin{array}{l}\text { Bank products addressed to marginalised groups (the } \\
\text { disabled, aged customers, non-profit organizations ... ) }\end{array}$ & 9 & $50.0 \%$ & 48 \\
\hline 21 & Examination of customer satisfaction/service quality & 11 & $61.1 \%$ & 57 \\
\hline 22 & Protection of customers' data and privacy & 8 & $44.4 \%$ & 40 \\
\hline 23 & $\begin{array}{l}\text { Customer service (settlement of problems, complaints, } \\
\text { disputes, renegotiation of contract terms ... ) }\end{array}$ & 9 & $50.0 \%$ & 43 \\
\hline 24 & Consumer awards & 13 & $72.2 \%$ & 63 \\
\hline 25 & $\begin{array}{l}\text { Community Involvement (CI) } \\
\text { Donations for social activities and public } \\
\text { benefit organizations }\end{array}$ & 16 & $88.9 \%$ & 108 \\
\hline 26 & $\begin{array}{l}\text { Support for education (scholarships, conferences, } \\
\text { seminars, student internships ... ) }\end{array}$ & 16 & $88.9 \%$ & 103 \\
\hline 27 & Sponsorship of various sport, artistic and cultural events & 15 & $83.3 \%$ & 98 \\
\hline 28 & $\begin{array}{l}\text { Sponsorship of various public health initiatives, } \\
\text { projects, campaigns }\end{array}$ & 13 & $72.2 \%$ & 54 \\
\hline 29 & $\begin{array}{l}\text { Support for local activities, industry, agriculture } \\
\text { Total average }\end{array}$ & 13 & $\begin{array}{l}72.2 \% \\
58.8 \%\end{array}$ & 66 \\
\hline
\end{tabular}

As stated in the previous section, in this study we considered 29 CSR reporting items, the detailed results of which are shown in Table 2. The results indicate that even though reporting of CSR was voluntary in Poland in the analyzed period (according to Matuszak and Różańska [60], since 2016 it has become obligatory due to EU Directive 2014/95/EU on non-financial disclosures) the participation of Polish commercial banks in different CSR activities varies among banks and is not as low as we might expect. There were only several banks which were involved in CSR activities to a large extent. The most commonly undertaken CSR activities (above 85\%) were donations for social activities and 
public benefit organizations ( $88.9 \%)$, and support for education $(88.9 \%)$. Moreover, each item was reported by at least one bank. It was observed that Polish banks report extensively about their human resources. A total of 15 banks reported about their employment and labor relations, as well as employee development. Furthermore, $83.3 \%$ of banks disclosed information related to the comprehensibility and transparency of products and services they provide. The CSR dimension that was least reported by banks is environment. The highest number of banks that reported a given item in this area was 10, and the lowest was 1 . This indicates that Polish banks need to improve their environmental activity. The average reporting score of $58.8 \%$ indicates that Polish commercial banks' CSR reporting is at the early stage of development.

Table 3. Development of lagged CSP disclosure indices for the years 2007 to 2014 .

\begin{tabular}{ccccc}
\hline Year & ENV & HR & PC & CI \\
\hline 2007 & 13.3 & 16.9 & 15.7 & 35.3 \\
2008 & 16.7 & 25.0 & 16.7 & 45.9 \\
2009 & 17.8 & 22.8 & 21.6 & 47.1 \\
2010 & 26.7 & 38.2 & 36.3 & 65.9 \\
2011 & 26.7 & 40.4 & 39.2 & 65.9 \\
2012 & 31.7 & 49.3 & 44.1 & 67.1 \\
2013 & 33.9 & 52.9 & 47.1 & 74.1 \\
2014 & 30.6 & 55.9 & 48.0 & 65.9 \\
Average & $\mathbf{2 4 . 7}$ & $\mathbf{3 7 . 7}$ & $\mathbf{3 3 . 6}$ & $\mathbf{5 8 . 4}$ \\
\hline
\end{tabular}

The basic descriptive statistics for the sample are given in Table 4. Regarding profitability measures, the sample was balanced as the minimum and maximum values of ROA were -6.43 and 6.15 , respectively. The mean score for NIM was $3.01 \%$ with a standard deviation of $1.82 \%$. This suggests that over the study period, NIM for the banks averaged about 3.01\%, with individual yearly figures differing around $1.82 \%$. Each of the CSR components revealed the same minimum and maximum values. It is evident from the descriptive statistics that the CSR indices showed great variation in their values. This indicates significant differences in CSR activities among Polish banks. Moreover, the median of ENV is zero, which means that at least half of the population did not report on environmental issues. The average value of Leverage means that the debt of the average bank exceeded 9.40 times its equity. This confirms Saunders and Cornett's [62] suggestion that banks are generally risky companies.

Table 4. Descriptive statistics.

\begin{tabular}{ccccccc}
\hline Variables & N & Mean & Median & Minimum & Maximum & St. dev. \\
\hline ROA (\%) & 144 & 0.96 & 0.92 & -6.43 & 6.15 & 1.04 \\
NIM (\%) & 144 & 2.94 & 2.65 & 0.23 & 11.27 & 1.71 \\
ENV (\%) & 144 & 22.50 & 0.00 & 0.00 & 100.00 & 29.55 \\
HR (\%) & 144 & 35.29 & 25.00 & 0.00 & 100.00 & 33.42 \\
PC (\%) & 144 & 33.56 & 17.00 & 0.00 & 100.00 & 33.64 \\
CI (\%) & 144 & 55.83 & 60.00 & 0.00 & 100.00 & 37.83 \\
LogTA & 144 & 3.41 & 3.61 & 0.56 & 5.59 & 1.20 \\
Leverage & 144 & 9.46 & 8.82 & 0.31 & 20.21 & 4.04 \\
WSE & 144 & 0.61 & 1.00 & 0.00 & 1.00 & 0.49 \\
\hline
\end{tabular}

\subsection{Pearson Correlation Analysis}

The correlation matrix is presented in Table 5. The results suggest that variables were not highly correlated with each other. The highest correlation was observed among CSR dimensions, however, their correlations do not raise concerns for any multicollinearity problems, as presented in variance inflation factor (VIF) values (all values were below 10). Further, the correlation of all CSR components with FP measures was rather low. An interesting observation is that ENV was negatively correlated and CI was positively correlated with all FP measures. These results suggest that examining CSR in 
aggregate form could lead to misleading conclusions, as the impacts of different dimensions could neutralize each other. In addition, Leverage was negatively and significantly correlated with all FP measures.

Table 5. Correlation matrix of variables.

\begin{tabular}{|c|c|c|c|c|c|c|c|c|c|c|}
\hline & VIF & ROA & NIM & ENV & HR & PC & CI & LogTA & Leverage & WSE \\
\hline ROA (\%) & & 1 & & & & & & & & \\
\hline NIM (\%) & & $0.208^{* *}$ & 1 & & & & & & & \\
\hline ENV (\%) & 2.070 & -0.022 & -0.105 & 1 & & & & & & \\
\hline HR (\%) & 4.246 & 0.125 & -0.051 & $0.575^{* *}$ & 1 & & & & & \\
\hline PC (\%) & 2.915 & 0.045 & -0.026 & $0.682 * *$ & $0.738 * *$ & 1 & & & & \\
\hline CI (\%) & 2.261 & 0.068 & 0.049 & $0.415^{* *}$ & $0.726 * *$ & $0.532 * *$ & 1 & & & \\
\hline LogTA & 2.333 & $0.239 * *$ & -0.056 & $0.209 * *$ & $0.595 * *$ & 0.304 & $0.539 * *$ & 1 & & \\
\hline Leverage & 1.049 & $-0.293 * *$ & $-0.200 * *$ & -0.109 & $-0.200 * *$ & -0.112 & -0.127 & -0.131 & 1 & \\
\hline WSE & 1.601 & $0.227^{* *}$ & -0.068 & $0.324^{* *}$ & $0.361 * *$ & $0.257^{* *}$ & $0.237^{* *}$ & 0.550 ** & -0.107 & 1 \\
\hline
\end{tabular}

\subsection{Multiple Regression Analysis}

Table 6 reports the regression results for the effects of CSR indices on FP. In linear specification, the results suggest that the effect of CSR dimensions on FP was mixed and insignificant. The ENV coefficient is negative and not significant for all measures of FP, whereas the PC coefficient is positive and not significant. Therefore, we cannot confirm Hypothesis 1 . Overall, these mixed results are partially in line with the findings of Nollet et al. [37] and Mittal et al. [58], among others. All control variables revealed no significance, with the exemption of Leverage for the ROA model.

Further, we employed the Ramsey RESET test to assess whether linear model specification was appropriate. According to this test, in both cases the linear model was not appropriate. Thus, following prior studies $[37,58]$ we assumed and estimated non-linear quadratic models. The non-linear specification revealed some rather interesting results, namely, that there existed both U-shaped and inverse-U-shaped relationships between CSR disclosure indices and FP in the Polish banking sector. These results confirm the intuition that the negative or positive relationships between individual CSR dimensions and FP in the linear specification could be a part of more complex non-linear relationship. Firstly, a U-shaped relationship between NIM and HR was revealed. Both HR and quadratic HR coefficients are significant and negative or positive, respectively. This relationship could be explained by the fact that, although a negative relationship between HR and NIM may occur at the beginning of HR, after achieving a minimum point, the development of HR picks up in the latter part of a U-shaped relationship. The knowledge of this minimum point may be crucial for managers in shaping HR policy and related CSR disclosures, due to their impact on the bank's financial results.

Secondly, our results confirmed the existence of an inverse-U-shaped relationship between CI and NIM, as well as between PC and ROA in Polish banks. An inverse-U-shaped relationship can be interpreted quite simply in the light of a general phenomenon in neoclassical economics called the law of diminishing marginal returns. If the input variable has a positive relationship with the output variable, then adding more of the input variable will, at some point, yield lower marginal returns per unit. In other words, the extent of the contribution from the former to the latter input variable on the output variable starts to decrease as the input amount accumulates. The same situation is observed in the CI and PC dimensions. When, for instance, $\mathrm{CI}$ increases, the marginal extent of its contribution to FP starts to decrease at a certain point. Our results indicate that CI and PC efforts made in Polish banks after a maximum point will not be beneficial in the long run. From the point of view of the bank manager, these maximum points should be important in shaping the CI and PC policies and related CSR disclosures, in connection with their impact on the bank's financial results. The above findings could also be confirmed by the linear specification, where in the cases of each of HR, CI and PC, the coefficients have the same sign—negative or positive, respectively-although their significance level is low. The abovementioned results partially confirm Hypothesis 2 in relation to 
HR, CI, and PC. These results are in contrast with the findings of Nollet et al. [37] and Han et al. [43], as they failed to find a non-linear relationship in the aggregated social area. Such an aggregate measure could neutralize opposite effects of its components on the descriptive variable. In our study on Polish banks, we found a U-shaped relationship in HR, and inverse-U-shaped relationships in CI and PC. This inconclusive result can be partially explained in the following way. In our research we assumed the social area to be proxied by three dimensions HR, CI, and PC. We would like to emphasize that this finding could fill the gap between the negative or positive relationships reported in previous research. In contrast with Han et al. [43] who found a U-shaped relationship in ENV, we cannot confirm the existence of a non-linear relationship between ENV and FP. This suggests that banks in Poland do not pay much attention to this category. It is possible that for banks this is not a priority dimension of CSR in achieving the desired financial result.

Moreover, it might be interesting to consider the minimum and maximum points for U-shaped and inverse-U-shaped relationships, respectively. First, based on the estimate of the non-linear coefficients of the HR and $\mathrm{HR}^{2}$ terms in specification no. 3 we calculated the minimum point. For HR the minimum point is 34.5. Comparing this result with the average value in 2014 (Table 3) of 55.9, it can be stated that the HR value has exceeded the minimum point. This suggests that improving the HR dimension is still helpful in improving the NIM, at least for Polish banks. Second, based on the estimate of non-linear coefficients of the $\mathrm{CI}$ and $\mathrm{CI}^{2}$ terms in specification no. 3, as well as of $\mathrm{PC}$ and $\mathrm{PC}^{2}$ terms in specification no. 4 , we computed maximum points. They were calculated to be 26.5 and 120 , respectively. In terms of CI, the stopping point (maximum) is much lower than the 2014 average CI value of 65.9 (Table 3). This result indicates that $\mathrm{CI}$ activities might not be beneficial in the long run, as they have a negative influence on NIM. The same cannot be stated in relation to PC, as the stopping point is much lower than the 2014 average PC value of 48.0 (Table 3). This indicates that Polish banks should increase engagement in the products and customers area, as it is still beneficial in terms of ROA. Finally, when it comes to the control variables, risk was significantly and negatively correlated with FP. However, LogTA and WSE variables were insignificant. All above mentioned findings suggest that Hypothesis 2 can be partially confirmed.

Table 6. CSR-FP relationship in linear and non-linear models, years 2008-2015.

\begin{tabular}{|c|c|c|c|c|c|c|c|c|}
\hline \multirow{3}{*}{ Variables } & \multicolumn{2}{|c|}{1} & \multicolumn{2}{|c|}{2} & \multicolumn{2}{|c|}{3} & \multicolumn{2}{|c|}{4} \\
\hline & \multicolumn{2}{|c|}{ Linear } & \multicolumn{2}{|c|}{ Linear } & \multicolumn{2}{|c|}{ Non-linear } & \multicolumn{2}{|c|}{ Non-linear } \\
\hline & \multicolumn{2}{|c|}{ NIM } & \multicolumn{2}{|c|}{ ROA } & \multicolumn{2}{|c|}{ NIM } & \multicolumn{2}{|c|}{ ROA } \\
\hline Intercept & 4.641 & $(2.807) * *$ & 1.256 & $(2.981)^{* *}$ & 4.049 & $(6.199) * * *$ & 1.054 & $(2.76)^{* * *}$ \\
\hline ENV & -0.012 & $(-1.133)$ & -0.006 & $(-1.797) *$ & 0.014 & $(0.658)$ & -0.014 & $(-1.139)$ \\
\hline $\mathrm{ENV}^{2}$ & & & & & 0.000 & $(-1.413)$ & 0.000 & $(0.808)$ \\
\hline HR & -0.008 & $(-0.533)$ & 0.002 & $(0.180)$ & -0.053 & $(-2.267) * *$ & 0.007 & $(0.506)$ \\
\hline $\mathrm{HR}^{2}$ & & & & & 0.001 & $(2.253) * *$ & -0.000 & $(-0.376)$ \\
\hline PC & 0.006 & $(0.802)$ & 0.002 & $(0.546)$ & 0.013 & $(0.642)$ & 0.024 & $(2.094) * *$ \\
\hline $\mathrm{PC}^{2}$ & & & & & 0.000 & $(-0.716)$ & -0.000 & $(-1.998) * *$ \\
\hline $\mathrm{CI}$ & 0.011 & (1.138) & -0.002 & $(-0.662)$ & 0.069 & $(3.262) * * *$ & -0.004 & $(-0.321)$ \\
\hline $\mathrm{CI}^{2}$ & & & & & -0.001 & $(-2.809)^{* * *}$ & -0.000 & $(-0.017)$ \\
\hline LogTA & -0.251 & $(-0.853)$ & 0.113 & $(0.851)$ & -0.202 & $(-1.11)$ & 0.109 & $(1.022)$ \\
\hline Leverage & -0.116 & $(-1.608)$ & -0.080 & $(-3.754)^{* * *}$ & -0.111 & $(-2.883)^{* * *}$ & -0.077 & $(-3.442) * * *$ \\
\hline WSE & 0.108 & $(0.098)$ & 0.368 & $(1.312)$ & 0.307 & $(0.793)$ & 0.394 & $(1.739) *$ \\
\hline F-statistics & $2.363 *$ & & $5.606^{* * *}$ & & $2.875^{* * *}$ & & $3.044^{* * *}$ & \\
\hline $\mathrm{N}$ & 144 & & 144 & & 144 & & 144 & \\
\hline R-squared ${ }^{1}$ & 0.11 & & 0.17 & & 0.19 & & 0.2 & \\
\hline Reset [F] & $6.67 * *$ & & $7.15^{* * *}$ & & & & & \\
\hline
\end{tabular}

$t$ statistics in parentheses; ${ }^{*} p<0.10,{ }^{* *} p<0.05,{ }^{* * *} p<0.01 .{ }^{1}$ R-squared is a measure of goodness of fit of the regression model and is traditionally associated with regression validation process.

\section{Robustness Check}

In order to examine the sensitivity of our results, we undertook several robustness tests, the results of which are presented in Table 6. As in our research, we have two dependent variables in Table 7; models 5-8 relate to the estimated coefficients for NIM and models 9-10 relate to ROA. In model 5, 
we substituted the proxy of size by the natural logarithm of net sales measured by interest and other operating income. Model 6 presents estimated coefficients if the NIM variable is substituted by the natural logarithm of NIM. Model 7 combines these two changes. In addition to model 7, in model 8 we substituted independent variables (disaggregated CSR measures) by the aggregated measure of CSR. In relation to ROA in model 9 we substituted the proxy of size by natural logarithm of net sales measured by interest and other operating income, and in model 10 we substituted independent variables (disaggregated CSR measures) by the aggregated measure of CSR. We could not substitute ROA by its natural logarithm, because in several cases ROA had negative values.

The results in models 5-7 remain robust and confirm the nonlinear relationship between NIM or LogNIM and CI, as the estimated coefficients are statistically significant. This we cannot say about NIM or LogNIM and HR. Although HR coefficients are statistically significant ( $p$-value $<0.01$ ), $\mathrm{HR}^{2}$ coefficients are not statistically significant $(p$-value $>0.1)$ in each model. This last case can be partially driven by low coefficient values which are almost zero, so it is probable that they could have negative values as well. In such cases the coefficients are losing significance. However, in the cases of both HR and CI, the shape of the relationship with FP was unchanged, which means U-shaped and inverse-U-shaped, respectively.

Regarding the ROA, the results of model 9 show a consistent inverse-U-shape relationship between ROA and PC. However, the coefficients are statistically significant at the $10 \%$ level $(p$-value $<0.1)$. As was expected, FP measures are not statistically significantly ( $p$-value $>0.1)$ correlated with the CSR aggregate measure in model 8 and 10. In each model from 5-10, FP is statistically significantly ( $p$-value $<0.01)$ and negatively correlated with Leverage. This confirms the relationship presented in models 1-4 (Table 6). Moreover, NIM and LogNIM is statistically significantly and positively correlated with size measured by natural logarithm of net sales (models $5,7,8$ ). This we cannot say in terms of ROA (models $5,7,8$ ). The overall tests confirm the relationship observed in our research. 
Table 7. CSR-FP relationship in non-linear models, years 2008-2015.

\begin{tabular}{|c|c|c|c|c|c|c|c|c|c|c|c|c|}
\hline \multirow{3}{*}{$\begin{array}{c}\text { Models } \\
\text { Variables } \\
\text { Intercept }\end{array}$} & \multicolumn{2}{|c|}{5} & \multicolumn{2}{|c|}{6} & \multicolumn{2}{|c|}{7} & \multicolumn{2}{|c|}{8} & \multicolumn{2}{|c|}{9} & \multicolumn{2}{|c|}{10} \\
\hline & \multicolumn{2}{|c|}{ NIM } & \multicolumn{2}{|c|}{ LogNIM } & \multicolumn{2}{|c|}{ LogNIM } & \multicolumn{2}{|c|}{ LogNIM } & \multicolumn{2}{|c|}{ ROA } & \multicolumn{2}{|c|}{ ROA } \\
\hline & 3.996 & $(7.34) * * *$ & 1.178 & $(7.276)^{* * *}$ & 1.118 & $(8.183)^{* * *}$ & 1.266 & $(9.522)^{* * * *}$ & 1.672 & $(5.403)^{* * *}$ & 1.540 & $(5.202)^{* * *}$ \\
\hline ENV & 0.017 & $(0.81)$ & 0.000 & $(0.022)$ & 0.001 & $(0.16)$ & & & -0.021 & $(-1.75) *$ & & \\
\hline $\mathrm{ENV}^{2}$ & 0.000 & $(-1.23)$ & 0.000 & $(-1.208)$ & 0.000 & $(-1.03)$ & & & 0.000 & $(1.341)$ & & \\
\hline $\mathrm{HR}$ & -0.067 & $(-3.01)^{* * * *}$ & -0.018 & $(3.048) * * * *$ & -0.021 & $(3.282)^{* * * *}$ & & & 0.010 & $(0.786)$ & & \\
\hline $\mathrm{HR}^{2}$ & 0.001 & $(0.85)$ & 0.000 & $(1.412)$ & 0.000 & (1.61) & & & -0.000 & $(-0.734)$ & & \\
\hline PC & 0.016 & $(0.85)$ & 0.007 & (1.412) & 0.008 & (1.61) & & & 0.021 & $(1.934) *$ & & \\
\hline $\mathrm{PC}^{2}$ & -0.000 & $(-0.71)$ & -0.000 & $(-1.266)$ & -0.000 & $(-1.25)$ & & & -0.000 & $(-1.763)^{*}$ & & \\
\hline CI & 0.065 & $(3.14) * * *$ & 0.020 & $(3.716)^{* * *}$ & 0.019 & $(3.612)^{* * *}$ & & & -0.003 & $(-0.26)$ & & \\
\hline $\mathrm{CI}^{2}$ & -0.001 & $(-3.01)^{* * *}$ & -0.000 & $(-2.94)^{* * *}$ & -0.000 & $(-3.143)^{* * *}$ & & & -0.000 & $(-0.071)$ & & \\
\hline CSR & & & & & & & 0.002 & $(0.455)$ & & & -0.001 & $(-0.104)$ \\
\hline $\mathrm{CSR}^{2}$ & & & & & & & -0.000 & $(-0.999)$ & & & 0.000 & $(-0.376)$ \\
\hline LogTA & & & -0.067 & $(-1.479)$ & & & & & & & & \\
\hline Leverage & -0.111 & $(-2.95)^{* * *}$ & -0.033 & $(-3.409) * * * *$ & -0.033 & $(-3.479)^{* * *}$ & -0.031 & $(-3.315)^{* * *}$ & -0.106 & $(-4.991)^{* * *}$ & -0.078 & $(-3.763)^{* * *}$ \\
\hline GPW & -0.469 & $(-1.21)$ & 0.241 & $(2.507)^{* *}$ & 0.054 & $(0.558)$ & -0.075 & $(-0.802)$ & 0.419 & $(1.898) *$ & 0.282 & $(1.355)$ \\
\hline LogNetSales & 0.488 & $(2.85)^{* * *}$ & & & 0.101 & $(2.359)^{* *}$ & 0.110 & $(2.819)^{* * *}$ & 0.096 & $(0.989)$ & 0.170 & $(1.95)^{*}$ \\
\hline $\mathrm{F}$ & $(3.64)^{* * * *}$ & & $(4.46)^{* * *}$ & & $(4.87) * * *$ & & $(4.97)^{* * * *}$ & & $(4.76)^{* * *}$ & & $(5.8)^{* * *}$ & \\
\hline $\mathrm{N}$ & 144 & & 144 & & 144 & & 144 & & 144 & & 144 & \\
\hline R-squared & 0.233 & & 0.271 & & 0.289 & & 0.153 & & 0.284 & & 0.174 & \\
\hline
\end{tabular}

$t$ statistics in parentheses; ${ }^{*} p<0.10,{ }^{* *} p<0.05,{ }^{* * *} p<0.01$ 


\section{Conclusions}

This study investigated the relationship between CSR dimensions and FP in Polish commercial banks. Particularly, we considered four CSR indices (i.e., HR, ENV, PC, CI) and accounting-based performance measures (i.e., NIM and ROA). Our control variables included Leverage, LogTA, and WSE. The data from the banking industry in Poland in the period of 2008-2015 provided the background for this study.

Two hypotheses were set in this study and one was partially supported. The findings of linear models suggest that there is no significant relationship between CSR and FP among Polish banks. However, further analysis of non-linear models revealed the existence of a U-shaped relationship between HR and NIM, and inverse-U-shaped relationships between CI and NIM, as well as PC and ROA. In the first case, the U-shaped relationship indicates that investing in $\mathrm{HR}$ and undertaking activities in this area may be beneficial after achieving a certain minimum point, before which additional HR expenditures may decrease FP. In the latter cases, inverse-U-shaped relationships denote that activities undertaken in the CI and PC areas may be beneficial before achieving a specific maximum threshold amount. In terms of CI, further expenditures are not supposed to be paid off, as the average maximum point in 2014 was exceeded almost twice. In relation to the PC area, further improvements should be undertaken as they might have a positive impact on FP, since the stopping point has not been exceeded. Our study also indicated that, when CSR is treated as a multidimensional construct, revealing and decomposing various areas of banks' commitments and undertaken activities could better convey their impact on FP. Thus, there is a need to use more detailed measures of CSR to obtain a clearer and more transparent relationship between CSR and FP.

The improved understanding of the CSR-FP relationship in the banking industry fills the knowledge gap in the empirical literature. This study has also some practical implications by providing policy suggestions for both bank managers and government regulators. Bank managers should convince the board to engage in different CSR activities as an important part of their strategic initiatives, and to allocate more resources to those that have significant positive relationships with FP and less to others, thereby improving overall stakeholder wellbeing and thus creating positive social change. Government regulators can encourage banks to adopt CSR, which creates profits and consequently increases the safety and soundness of the banking system. Furthermore, engaging in CSR could increase social welfare, which is improved by focusing on the needs of employees, clients, and communities.

It should also be noted that this study may also have some potential consequences for prioritizing the most profitable CSR initiatives, in relation to those that could more clearly improve society. Profit-based CSR studies show that some activities are more valuable than others but they do not measure social benefits. Scherer and Palazzo [63] state that those activities considered inefficient or insufficiently visible risk a lack of interest from businesses, and that risk increases when businesses gain political support. Sandoval [64] claims that the logic of this 'instrumental reductionist approach' will cause companies to reject the idea of CSR, as soon as costs outweigh the benefits. Farrington et al. [4] argue that these studies confirm the potential for corruption in businesses that perceive CSR activities as a highly visible means to entirely private ends. Neu et al. [65] notice also that this financial emphasis may lead to such activities that restore organisational legitimacy to management. To sum up, prioritizing CSR activities only on the basis of financial results may harm the weakest stakeholders and lead to social inequalities and environmental degradation. Ultimately, the potential consequences outlined above depend on the motivations of the people who run and govern each company, each bank.

From the above, the main limitation of this study is the focus on CSR as a public means to private ends, although current literature in the fields of management, politics, and sociology generally suggests that the dominant emphasis on business justification of CSR is in contradiction with the basic goals of dealing with social responsibilities $[4,66]$. Future research may be based on a wider theoretical approach that should give greater primary consideration to social and environmental benefits. 
Another limitation of the study is our focus on the banking sector in Poland. This limits the ability of generalization of the results to other corporate sectors. Future research may replicate the methodology of the study for the banking sectors of other countries. Moreover, some parts of the methodology could be adapted in further research examining the linkage of CSR dimensions and FP in many other sectors, such as oil and gas, food, and manufacturing or production sectors, in order to obtain more understanding of the differences amongst them.

Author Contributions: Both authors wrote the paper and their contribution in each section was $50 \%$ each.

Funding: This research received no external funding.

Acknowledgments: The authors would like to thank the four anonymous reviewers for their useful comments that have greatly improved the manuscript, needless to say that any shortcomings are the responsibilities of the authors alone. In addition, we are grateful to the participants of three conferences: VIII International Scientific Conference entitled: Financial Reporting and Auditing: Challenges and Opportunities for Accounting Researchers and Educators in Cracow, organized by International Association for Accounting Education \& Research (IAAER) and Cracow University of Economics, 26-27 September 2017, The International Conference Accounting and Management Information Systems AMIS 2018 organized by Bucharest University of Economic Studies, 13-14 June 2018 and Accounting and Accountability in Emerging Economies (AAEE) Conference 2018, 28-29 June 2018 organized by Essex Business School in Great Britain, for their helpful comments and interesting discussion. Also, we would like to thank Przemysław Garsztka (Department of Econometrics, Poznań University of Economics and Business) for friendly and valuable discussion about econometric modeling in the research.

Conflicts of Interest: The authors declare no conflict of interest.

\section{Appendix A}

\section{CSR dimension items}

\begin{tabular}{|c|c|}
\hline \multicolumn{2}{|c|}{ Environment } \\
\hline EN1 & Statement on environmental protection policy \\
\hline EN2 & Prevention of pollution (waste disposal and recycling) \\
\hline EN3 & Actions aiming to limit consumption of energy, materials, water (sustainable use of resources) \\
\hline EN4 & Sustainability (any mention of sustainable development) \\
\hline EN5 & Aesthetic value of the environment (designing structures in harmony with the environment, landscape) \\
\hline EN6 & Environmental protection, biodiversity and restoration of natural habitats \\
\hline EN7 & $\begin{array}{l}\text { Taking account of the environment in credit policy (environmentally-friendly products, 'green products', } \\
\text { funding 'low-emission' investment projects ... ) }\end{array}$ \\
\hline EN8 & Environmental training and certificates (ISO $14001 \mathrm{vs)}$ \\
\hline EN9 & Joint projects with other companies providing environmental management services \\
\hline EN10 & Environmental awards \\
\hline \multicolumn{2}{|c|}{ Human Resources } \\
\hline HR1 & Employment and labour relations \\
\hline HR2 & Occupational health and safety \\
\hline HR3 & Employee development (training ... ) \\
\hline HR4 & Employee benefits (insurance, healthcare, social assistance ... ) \\
\hline HR5 & Relationships with trade unions \\
\hline HR6 & Information on employee turnover \\
\hline HR7 & Information on support for daytime care, maternity and paternity leave \\
\hline HR8 & Encouraging diversity (employment of minorities, disabled persons, women ... ) \\
\hline \multicolumn{2}{|c|}{ Product and customers } \\
\hline PC1 & Comprehensibility and transparency of products/services \\
\hline PC2 & Bank products addressed to marginalised groups (the disabled, aged customers, non-profit organisations ... ) \\
\hline PC3 & Examination of customer satisfaction/service quality \\
\hline PC4 & Protection of customers' data and privacy \\
\hline PC5 & Customer service (settlement of problems, complaints, disputes, renegotiation of contract terms ... ) \\
\hline PC6 & Consumer awards \\
\hline
\end{tabular}




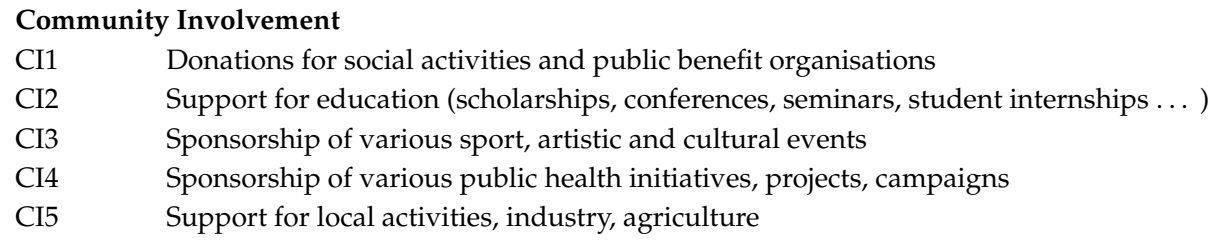

\section{References}

1. European Commission. Summary Report of the Responses Received to the Public Consultation on Disclosure of Non-Financial Information by Companies, Directorate General for the Internal Market and Services. Retrieved; European Commission: Brussels, Belgium, 2011.

2. Lee, M.-D.P. A review of the theories of corporate social responsibility: Its evolutionary path and the road ahead. Int. J. Manag. Rev. 2008, 10, 53-73. [CrossRef]

3. Freeman, R.E.; Harrison, J.S.; Wicks, A.C.; Parmar, B.; de Colle, S. Stakeholder Theory: The State of the Art; Cambridge University Press: Cambridge, UK; New York, NY, USA, 2010.

4. Farrington, T.; Curran, R.; Gori, K.; O'Gorman, K.D.; Queenan, C.J. Corporate social responsibility: Reviewed, rated, revised. Int. J. Contemp. Hosp. Manag. 2017, 29, 30-47. [CrossRef]

5. Grewatsch, S.; Kleindienst, I. When Does It Pay to be Good?: Moderators and Mediators in the Corporate Sustainability-Corporate Financial Performance Relationship: A Critical Review. J. Bus. Ethics 2017, 145, 383-416. [CrossRef]

6. Blanco, B.; Guillamón-Saorín, E.; Guiral, A. Do Non-socially Responsible Companies Achieve Legitimacy Through Socially Responsible Actions?: The Mediating Effect of Innovation. J. Bus. Ethics 2013, 117, 67-83. [CrossRef]

7. Godfrey, P.C.; Merrill, C.B.; Hansen, J.M. The relationship between corporate social responsibility and shareholder value: An empirical test of the risk management hypothesis. Strateg. Manag. J. 2009, 30, 425-445. [CrossRef]

8. Hull, C.E.; Rothenberg, S. Firm performance: The interactions of corporate social performance with innovation and industry differentiation. Strateg. Manag. J. 2008, 29, 781-789. [CrossRef]

9. Servaes, H.; Tamayo, A. The Impact of Corporate Social Responsibility on Firm Value: The Role of Customer Awareness. Manag. Sci. 2013, 59, 1045-1061. [CrossRef]

10. Wang, H.; Choi, J. A New Look at the Corporate Social-Financial Performance Relationship. J. Manag. 2011, 39, 416-441. [CrossRef]

11. Flammer, C. Corporate Social Responsibility and Shareholder Reaction: The Environmental Awareness of Investors. Acad. Manag. J. 2013, 56, 758-781. [CrossRef]

12. El Ghoul, S.; Guedhami, O.; Kwok, C.C.Y.; Mishra, D. Does corporate social responsibility affect the cost of capital? J. Bank. Financ. 2011, 35, 2388-2406. [CrossRef]

13. Goss, A.; Roberts, G.S. The impact of corporate social responsibility on the cost of bank loans. J. Bank. Financ. 2011, 35, 1794-1810. [CrossRef]

14. Jo, H.; Harjoto, M.A. Corporate Governance and Firm Value: The Impact of Corporate Social Responsibility. J. Bus. Ethics 2011, 103, 351-383. [CrossRef]

15. Shen, C.-H.; Wu, M.-W.; Chen, T.-H.; Fang, H. To engage or not to engage in corporate social responsibility: Empirical evidence from global banking sector. Econ. Model. 2016, 55, 207-225. [CrossRef]

16. Baird, P.L.; Geylani, P.C.; Roberts, J.A. Corporate Social and Financial Performance Re-Examined: Industry Effects in a Linear Mixed Model Analysis. J. Bus. Ethics 2012, 109, 367-388. [CrossRef]

17. Wang, T.; Bansal, P. Social responsibility in new ventures: Profiting from a long-term orientation. Strateg. Manag. J. 2012, 33, 1135-1153. [CrossRef]

18. Busch, T.; Hoffmann, V.H. How Hot Is Your Bottom Line?: Linking Carbon and Financial Performance. Bus. Soc. 2011, 50, 233-265. [CrossRef]

19. Schreck, P. Reviewing the Business Case for Corporate Social Responsibility: New Evidence and Analysis. J. Bus. Ethics 2011, 103, 167-188. [CrossRef] 
20. Gilley, K.M.; Worrell, D.L.; Davidson, W.N.; El-Jelly, A. Corporate Environmental Initiatives and Anticipated Firm Performance: The Differential Effects of Process-Driven Versus Product-Driven Greening Initiatives. J. Manag. 2000, 26, 1199-1216. [CrossRef]

21. Surroca, J.; Tribó, J.A.; Waddock, S. Corporate responsibility and financial performance: The role of intangible resources. Strateg. Manag. J. 2010, 31, 463-490. [CrossRef]

22. Soana, M.-G. The Relationship Between Corporate Social Performance and Corporate Financial Performance in the Banking Sector. J. Bus. Ethics 2011, 104, 133. [CrossRef]

23. Jayachandran, S.; Kalaignanam, K.; Eilert, M. Product and environmental social performance: Varying effect on firm performance. Strateg. Manag. J. 2013, 34, 1255-1264. [CrossRef]

24. Van der Laan, G.; van Ees, H.; van Witteloostuijn, A. Corporate Social and Financial Performance: An Extended Stakeholder Theory, and Empirical Test with Accounting Measures. J. Bus. Ethics 2008, 79, 299-310. [CrossRef]

25. Kim, Y.; Statman, M. Do Corporations Invest Enough in Environmental Responsibility? J. Bus. Ethics 2012, 105, 115-129. [CrossRef]

26. Brammer, S.; Millington, A. Does it pay to be different?: An analysis of the relationship between corporate social and financial performance. Strateg. Manag. J. 2008, 29, 1325-1343. [CrossRef]

27. Griffin, J.J.; Mahon, J.F. The Corporate Social Performance and Corporate Financial Performance Debate. Bus. Soc. 1997, 36, 5-31. [CrossRef]

28. Galant, A.; Cadez, S. Corporate social responsibility and financial performance relationship: A review of measurement approaches. Econ. Res. Ekonomska Istraživanja 2017, 30, 676-693. [CrossRef]

29. Graafland, J.J.; Eijffinger, S.C.W.; SmidJohan, H. Benchmarking of Corporate Social Responsibility: Methodological Problems and Robustness. J. Bus. Ethics 2004, 53, 137-152. [CrossRef]

30. Ruf, B.M.; Muralidhar, K.; Brown, R.M.; Janney, J.J.; Paul, K. An Empirical Investigation of the Relationship Between Change in Corporate Social Performance and Financial Performance: A Stakeholder Theory Perspective. J. Bus. Ethics 2001, 32, 143-156. [CrossRef]

31. Tang, Z.; Hull, C.E.; Rothenberg, S. How Corporate Social Responsibility Engagement Strategy Moderates the CSR-Financial Performance Relationship. J. Manag. Stud. 2012, 49, 1274-1303. [CrossRef]

32. Wu, M.-W.; Shen, C.-H. Corporate social responsibility in the banking industry: Motives and financial performance. J. Bank. Financ. 2013, 37, 3529-3547. [CrossRef]

33. Moura-Leite, R.C.; Padgett, R.C.; Galán, J.I. Stakeholder Management and Nonparticipation in Controversial Business. Bus. Soc. 2013, 53, 45-70. [CrossRef]

34. Scholtens, B. A note on the interaction between corporate social responsibility and financial performance. Ecol. Econ. 2008, 68, 46-55. [CrossRef]

35. Lioui, A.; Sharma, Z. Environmental corporate social responsibility and financial performance: Disentangling direct and indirect effects. Ecol. Econ. 2012, 78, 100-111. [CrossRef]

36. Margolis, J.D.; Elfenbein, H.A.; Walsh, J.P. Does It Pay to Be Good ... And Does it Matter? A Meta-Analysis of the Relationship between Corporate Social and Financial Performance. 2009. Available online: https: / / papers.ssrn.com/sol3/papers.cfm?abstract_id=1866371 (accessed on 20 March 2018).

37. Nollet, J.; Filis, G.; Mitrokostas, E. Corporate social responsibility and financial performance: A non-linear and disaggregated approach. Econ. Model. 2016, 52, 400-407. [CrossRef]

38. Peloza, J. The Challenge of Measuring Financial Impacts From Investments in Corporate Social Performance. J. Manag. 2009, 35, 1518-1541. [CrossRef]

39. Manasakis, C.; Mitrokostas, E.; Petrakis, E. Certification of corporate social responsibility activities in oligopolistic markets. Can. J. Econ./Revue Canadienne d'économique 2013, 46, 282-309. [CrossRef]

40. García-Gallego, A.; Georgantzís, N. Market Effects of Changes in Consumers' Social Responsibility. J. Econ. Manag. Strategy 2009, 18, 235-262. [CrossRef]

41. Barnett, M.L.; Salomon, R.M. Beyond dichotomy: The curvilinear relationship between social responsibility and financial performance. Strateg. Manag. J. 2006, 27, 1101-1122. [CrossRef]

42. Barnett, M.L.; Salomon, R.M. Does it pay to be really good?: Addressing the shape of the relationship between social and financial performance. Strateg. Manag. J. 2012, 33, 1304-1320. [CrossRef]

43. Han, J.-J.; Kim, H.J.; Yu, J. Empirical study on relationship between corporate social responsibility and financial performance in Korea. AJSSR 2016, 1, 61-76. [CrossRef]

44. Chih, H.-L.; Chih, H.-H.; Chen, T.-Y. On the Determinants of Corporate Social Responsibility: International Evidence on the Financial Industry. J. Bus. Ethics 2010, 93, 115-135. [CrossRef] 
45. Kang, H.-H.; Liu, S.-B. Corporate social responsibility and corporate performance: A quantile regression approach. Qual. Quant. 2014, 48, 3311-3325. [CrossRef]

46. Becchetti, L.; Ciciretti, R.; Hasan, I.; Kobeissi, N. Corporate social responsibility and shareholder's value. J. Bus. Res. 2012, 65, 1628-1635. [CrossRef]

47. Torres, A.; Bijmolt, T.H.A.; Tribó, J.A.; Verhoef, P. Generating global brand equity through corporate social responsibility to key stakeholders. Int. J. Res. Mark. 2012, 29, 13-24. [CrossRef]

48. Chen, C.-M.; Delmas, M. Measuring Corporate Social Performance: An Efficiency Perspective. Prod. Oper. Manag. 2011, 20, 789-804. [CrossRef]

49. McWilliams, A.; Siegel, D.S.; Wright, P.M. Corporate Social Responsibility: Strategic Implications. J. Manag. Stud. 2006, 43, 1-18. [CrossRef]

50. Bowman, E.H.; Haire, M. A Strategic Posture toward Corporate Social Responsibility. Calif. Manag. Rev. 1975, 18, 49-58. [CrossRef]

51. Matuszak, Ł.; Różańska, E. An examination of the relationship between CSR disclosure and financial performance: The case of Polish banks. JAMIS 2017, 16. [CrossRef]

52. Fijałkowska, J.; Zyznarska-Dworczak, B.; Garsztka, P. The relation between the CSR and the accounting information system data in Central and Eastern European (CEE) countries-The evidence of the Polish financial institutions. JAMIS 2017, 16, 490-521. [CrossRef]

53. Cornett, M.M.; Erhemjamts, O.; Tehranian, H. Greed or good deeds: An examination of the relation between corporate social responsibility and the financial performance of U.S. commercial banks around the financial crisis. J. Bank. Financ. 2016, 70, 137-159. [CrossRef]

54. Wierzba, R.; Gostomski, E.; Penczar, M.; Liszewska, M.; Górski, P.; Giżyński, J.; Małecka, E. Polski sektor bankowy wobec wyzwań zwiazanych z kryzysem finansowym w strefie euro; Wydział Zarządzania Uniwersytetu Gdańskiego: Sopot, Poland, 2014.

55. Freeman, R.E. Strategic Management: A Stakeholder Approach; University of Minnesota Press: San Bernardino, CA, USA, 2014.

56. Khlif, H.; Guidara, A.; Souissi, M. Corporate social and environmental disclosure and corporate performance. J. Account. Emerg. Econ. 2015, 5, 51-69. [CrossRef]

57. Friedman, M. The Social Responsibility of Business Is to Increase Its Profits. In Corporate Ethics and Corporate Governance; Zimmerli, W.C., Holzinger, M., Richter, K., Eds.; Springer: Berlin/Heidelberg, Geramny, 2007; pp. 173-178.

58. Mittal, R.K.; Sinha, N.; Singh, A. An analysis of linkage between economic value added and corporate social responsibility. Manag. Decis. 2008, 46, 1437-1443. [CrossRef]

59. Simpson, W.G.; Kohers, T. The Link Between Corporate Social and Fiancial Performace: Evidence from Banking Industry. J. Bus. Ethics 2002, 35, 97-109. [CrossRef]

60. Matuszak, Ł.; Różańska, E. CSR Disclosure in Polish-Listed Companies in the Light of Directive 2014/95/EU Requirements: Empirical Evidence. Sustainability 2017, 9, 2304. [CrossRef]

61. Wooldridge, J.M. Introductory Econometrics: A Modern Approach, 5th ed.; Cengage Learning: Mason, $\mathrm{OH}$, USA, 2013.

62. Saunders, A.; Cornett, M.M. Financial Institutions Management: A Risk Management Approach, 8th ed.; McGraw-Hill Education: New York, NY, USA, 2014.

63. Scherer, A.G.; Palazzo, G. The New Political Role of Business in a Globalized World: A Review of a New Perspective on CSR and its Implications for the Firm, Governance, and Democracy. J. Manag. Stud. 2011, 48, 899-931. [CrossRef]

64. Sandoval, M. From CSR to RSC. Rev. Rad. Polit. Econ. 2015, 47, 608-624. [CrossRef]

65. Neu, D.; Warsame, H.; Pedwell, K. Managing Public Impressions: Environmental Disclosures in Annual Reports. Account. Organ. Soc. 1998, 23, 265-282. [CrossRef]

66. Coles, T.; Fenclova, E.; Dinan, C. Tourism and corporate social responsibility: A critical review and research agenda. Tour. Manag. Perspect. 2013, 6, 122-141. [CrossRef]

(C) 2019 by the authors. Licensee MDPI, Basel, Switzerland. This article is an open access article distributed under the terms and conditions of the Creative Commons Attribution (CC BY) license (http://creativecommons.org/licenses/by/4.0/). 